\title{
Characterization of Spatio-temporal Trends in Long- term Rainfall of Three Weather Stations in Benin: Implications for Agricultural Decision Making.
}

Moudjahid Akorédé WABI ( $\nabla$ wmouako@yahoo.fr)

University of Ghent: Universiteit Gent https://orcid.org/0000-0003-1854-7306

\section{Wouter Vanhove}

University of Ghent: Universiteit Gent

Rodrigue Idohou

University of Ghent: Universiteit Gent

Achille Hounkpèvi

University of Ghent: Universiteit Gent

Romain Lucas Glèlè Kakaï

University of Ghent: Universiteit Gent

\section{Patrick Van Damme}

University of Ghent: Universiteit Gent

\section{Research Article}

Keywords: Climate change, rainfall, biometeorology, risk management, agriculture, adaptation

Posted Date: December 30th, 2021

DOI: https://doi.org/10.21203/rs.3.rs-1140845/v1

License: (9) (i) This work is licensed under a Creative Commons Attribution 4.0 International License.

Read Full License 


\title{
TITLE PAGE
}

\section{TITLE OF THE MANUSCRIT}

Characterization of spatio-temporal trends in long-term rainfall of three weather stations in Benin: implications for agricultural decision making.

\section{LIST OF AUTHOR NAMES, AFFILIATION(S), AND E-MAIL ADDRESSES}

* Authors: Moudjahid Akorédé Wabi ${ }^{(1,2)^{*}}$, Wouter Vanhove ${ }^{(1)}$, Rodrigue Idohou ${ }^{(2,3)}$, Achille Hounkpèvi ${ }^{(2)}$, Romain Lucas Glèlè Kakaï (2), Patrick Van Damme ${ }^{(1,4)}$

\section{* Affiliations}

(1) Laboratory of Tropical and Subtropical Agriculture and Ethnobotany (LTSAE), Faculty of Bioscience Engineering, Ghent University, Coupure Links 653, 9000 Ghent (Belgium).

*E-mail: wmouako@yahoo.fr

(2) Laboratoire de Biomathématiques et d'Estimations Forestière, Faculté des Sciences Agronomiques, Université d'Abomey-Calavi, 04 BP 1525 Cotonou (Bénin).

(3) Ecole de Gestion et de Production Végétale et Semencière, Université Nationale d'Agriculture, BP 43 Kétou (Bénin).

(4) Faculty of Tropical AgriSciences, Czech University of Life Sciences, Prague, Kamycka 129, 16521 Prague 6-Suchdol (Czech Republic).

\section{* Corresponding author : Moudjahid Akorédé Wabi}

* The active e-mail address of the corresponding author : wmouako@yahoo.fr

\begin{abstract}
A better understanding of rainfall variability and trends is vital for agricultural production systems. This study evaluates the spatio-temporal variability and trends in annual, seasonal and daily rainfall in Benin. Daily rainfall data for the 1970-2016 period measured at three weather stations (Savè, Malanville, and Tanguiéta) were obtained from the Benin National Weather Agency. Descriptive statistics, standardized anomaly of rainfall (SAR) and rainfall intensity were used to analyze rainfall variability. For rainfall trends analysis, we tested for auto-correlation and used the Mann-Kendall and Modified Mann-Kendall tests for non-auto-correlated and auto-correlated data, respectively. Trend magnitude was estimated using Sen's slope. Globally a moderate-to-high seasonal rainfall and low variability of yearly rainfall were observed. The SAR indicated more than $50 \%$ of the years in the studies period experienced dry years. Between 1970 and 2016, a significant $20 \%$ increase was observed in the yearly rainfall in Tanguiéta whereas no significant trends were observed in Malanville (10\% increase) and Savè $(0.6 \%$ decrease). The general rainfall increase observed during the post-monsoon season (October to November) in the three weather stations potentially increases flood frequencies during the harvest period of some crops, which can reduce crop yields. The changes in the pre-monsoon season (March to May) and monsoon season (June to September) were not globally uniform and can have positive/negative impact on agriculture, certainly when no adaptation strategies are applied. These findings are essential to the resilience building and climate risk management in agriculture which is largely dependent on weather conditions.
\end{abstract}

Keywords: Climate change, rainfall, biometeorology, risk management, agriculture, adaptation.

\section{Acknowledgments}

This work was supported by Ghent University (UGENT) [scholarship code: 01W00414, 2014]; and International Foundation for Science [Grant Agreement $N^{\circ}$ C/5762-1, 2015]. Our acknowledgment also goes to Dr Sylvanus Mensah, whose useful comments helped improve the quality of this document. 


\section{Introduction}

The impacts of human activities on the global climate have been amply documented. Human activities have significantly increased the concentration of greenhouse gases (GHG) in the atmosphere, contributing to global warming and adverse climatic changes (IPCC 2021; Tang et al. 2021). The sixth report from the Intergovernmental Panel on Climate Change (IPCC) indicates that human activities are largely responsible for the increase of $1^{\circ} \mathrm{C}$ in the global average temperature since the mid-20 $0^{\text {th }}$ century (IPCC 2021). By 2030, the report indicates that the increase in global temperature is expected to reach $1.5^{\circ} \mathrm{C}$. However, it is noted that the changes in rainfall are not globally uniform (Ademe et al. 2020; IPCC 2021), and are expected to vary across regions, since rain is a variable that change with time and space (Akumaga and Tarhule 2018; IPCC 2021). Considerable temporal and spatial climate variations might exist between different regions (Akinsanola and Ogunjobi 2017; Ademe et al. 2020).

In West Africa, agriculture is largely rain-fed (Onyutha 2018; Arouna et al. 2021). As a result, high intra- and inter-annual variability and uncertainties in rainfall (Sylla et al. 2015; Akumaga and Tarhule 2018) may affect the success of growing seasons or have important implications for water availability on which agriculture largely depends. One of the challenges faced in the study on climate change and climate variability is the ability to ascertain, identify and quantify the trends in rainfall and their implications for agricultural production systems. The latter information can guide suitable adaptation measures such as water conservation techniques, use of shallow ground water for irrigation, shifting planting dates and use of drought-resistant crop varieties (Marie et al. 2020). Rainfall trend analysis plays an important role for water resources management (Paul et al. 2017) and agricultural activities (Ademe et al. 2020). A change in the rainfall pattern may ultimately lead to drought and flood in different regions, which has a direct impact on soil degradation and agricultural productivity (Gummadi et al. 2018; Asfaw et al. 2018; Onyutha 2018; Arouna et al. 2021). Information about spatio-temporal trends in long-term rainfall is therefore essential for both farmers and agronomists (Ademe et al. 2020).

As is the case in most West African countries, Beninese agriculture is mostly rain-fed (AGVSA 2017; MCVDD 2019; Wabi et al. 2021). Agriculture accounts for 35\% of the Beninese Gross Domestic Product (GDP) and 75\% of the export revenue (AGVSA 2017). Around 70\% of people are dependent on agriculture for their livelihoods (MAEP 2017). In recent years, climate change and hydro-meteorological disasters such as drought and flood have caused severe damages to the agricultural sector and peoples' livelihood in different Beninese regions (Cornelissen et al. 2013; Aho et al. 2018; MCVDD 2019). By 2030, the third national communication on climate change (the latest) of Benin reported that future climate variability and climate change are likely to affect agriculture and increase the probabilities of occurrence of water scarcity and hunger (MCVDD 2019).

In recent years, there has been an increased interest in investigating long-term trends in rainfall data (Akinsanola and Ogunjobi 2017; Paul et al. 2017; Lawin et al. 2019; Ademe et al. 2020). For trend identification and the longitudinal quantification of climatological variables, parametric and non-parametric tests are generally used (Paul et al. 2017; Asfaw et al. 2018; Ademe et al. 2020). The Mann-Kendall (MK) statistical test (a non-parametric test), derived from studies of Mann (1975), Kendall (1975), and Yue et al. (2002), has been recommended by the World Meteorological Organization (WMO) as an effective means to assess trends in environmental data series. As such, the MK test has widely been used to verify the significance of trends in climatological or hydrological time series (Asfaw et al. 2018; Lawin et al. 2019; Ademe et al. 2020; Wabi et al. 2021) 
Our study takes places on the background of contradictory findings in previous studies of Benin climate trends. Gnanglè et al. (2011) analysed the spatio-temporal patterns of annual rainfall in Benin between 1960 and 2008 and reported a decreasing trend in national yearly rainfall and in the mean number of rainy days. On the other hand, Ahokpossi (2018) did not find a significant rainfall change in Benin. Lawin et al. (2019) investigated rainfall at the regional scale for the 1981-2010 period over the Mono River watershed (Southern part of Benin) and found an increasing trend. Idrissou et al. (2020) reported increasing annual rainfall in dry and sub-humid tropical zones of Benin between 1976 and 2015. Other studies investigated rainfall trends in Benin using an arbitrary period (28-year data), due to the availability of data, reported a decrease in annual rainfall (Ezin et al. 2018). However, approaches used by the latter authors (i) were based on unsuitable statistical methods and did not estimate the trend magnitude; and (ii) fell short of accounting for auto-correlation in the data. Many studies have highlighted the common problem of autocorrelation in time series analysis that affects the accuracy of the analyses (Hamed and Rao 1998; Yue et al. 2002; Akinsanola and Ogunjobi 2017; Paul et al. 2017; Ahokpossi 2018).

In this study, we explore spatio-temporal variability and trends in annual, seasonal, and daily rainfall using 47-year daily rainfall data collected from three weather stations in Benin. Specifically, this study aims to (i) analyze the variability of annual, seasonal and daily rainfall, and (ii) quantify the significance of changes by applying nonparametric (Mann-Kendall and Sen's slope) statistical tests on annual, seasonal and daily rainfall. We hypothesize that (i) increasing trend and variability of annual, seasonal, and daily rainfall occurs in the study area; and (ii) changes and variability of annual, seasonal, and daily rainfall are negatively linked with crop production which impacts agricultural practices. The results of this study can provide useful information for better planning water resources management and help to design appropriate adaptation measures in agriculture which is largely dependent on weather conditions.

\section{Material and methods}

\subsection{Study area and data}

The weather stations of Malanville, Savè, and Tanguiéta (Table 1 and Fig. 1) located in the agro-ecological regions of Sudano-Sahelian zone of the extreme North, the Sudano-Guinean transition zone and the Sudanese North-West zone respectively, were selected as our study sites. These three agro-ecological regions have different rainfall patterns (Fig. 2). Crop cultivation and livestock rearing are the main activities of the local population in the three agroecological zones (AGVSA 2017). Daily rainfall data were obtained from the Benin National Weather Agency for the 1970 to 2016 period (47-years).

Table 1 Description of the three weather stations

\begin{tabular}{llll}
\hline Weather stations & Malanville & Savè & Tanguiéta \\
\hline Latitude & $11^{\circ} 52^{\prime} \mathrm{N}$ & $7^{\circ} 59^{\prime} \mathrm{N}$ & $10^{\circ} 37^{\prime} \mathrm{N}$ \\
Longitude & $3^{\circ} 26^{\prime} \mathrm{E}$ & $2^{\circ} 26^{\prime} \mathrm{E}$ & $1^{\circ} 16^{\prime} \mathrm{E}$ \\
Elevation & $160 \mathrm{~m}$ & $199 \mathrm{~m}$ & $225 \mathrm{~m}$ \\
Bioclimatic region & Sudano-Sahelian & Sudano-Guinean & Sudanian \\
Annual rainfall & $700-1000 \mathrm{~mm}$ & 1100 to $1300 \mathrm{~mm}$ & 800 to $1100 \mathrm{~mm}$ \\
\hline
\end{tabular}

Data sources: Lawin et al. (2016) and MCVDD (2019). 


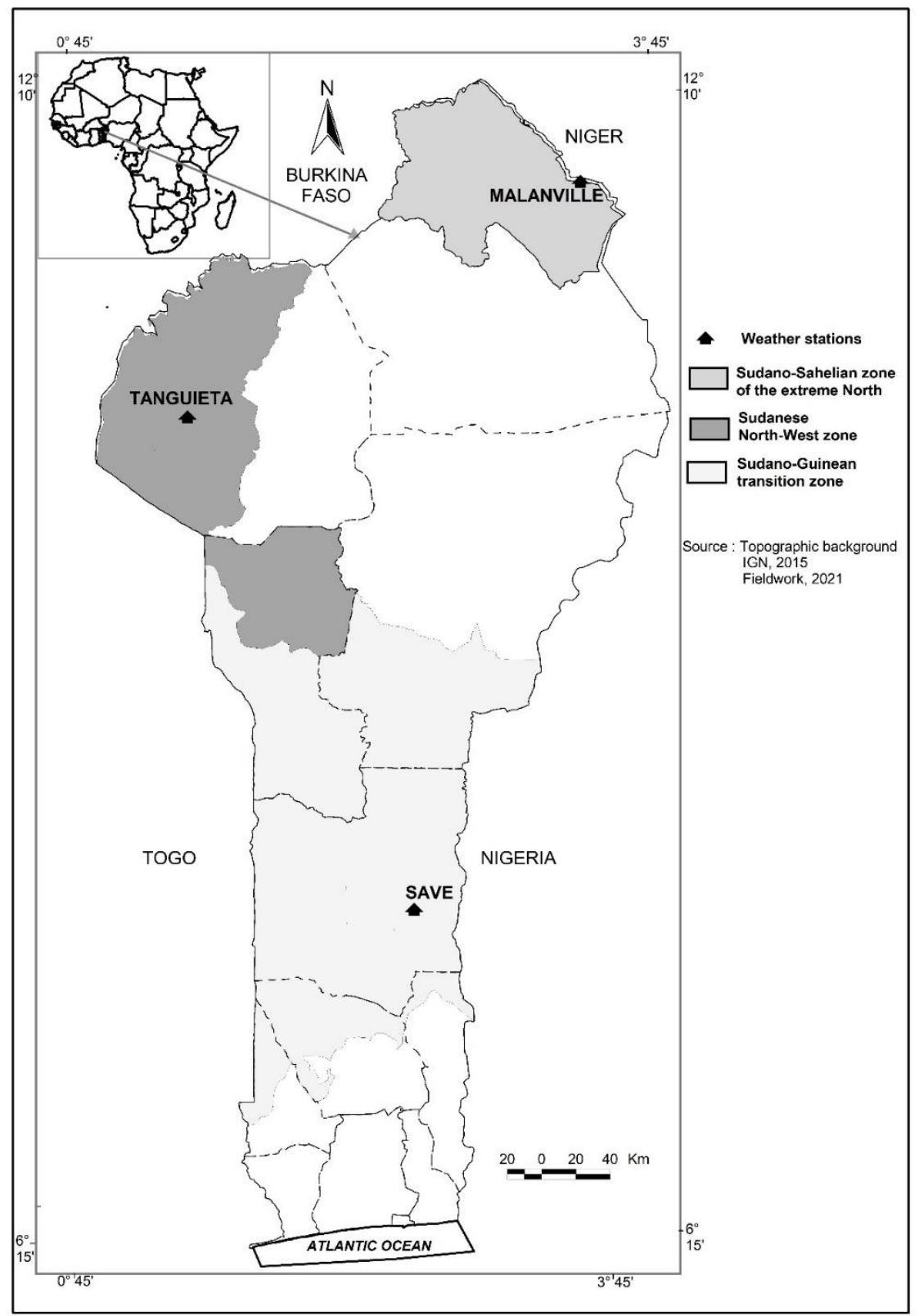

Fig. 1 Spatial distribution of the weather stations in Benin

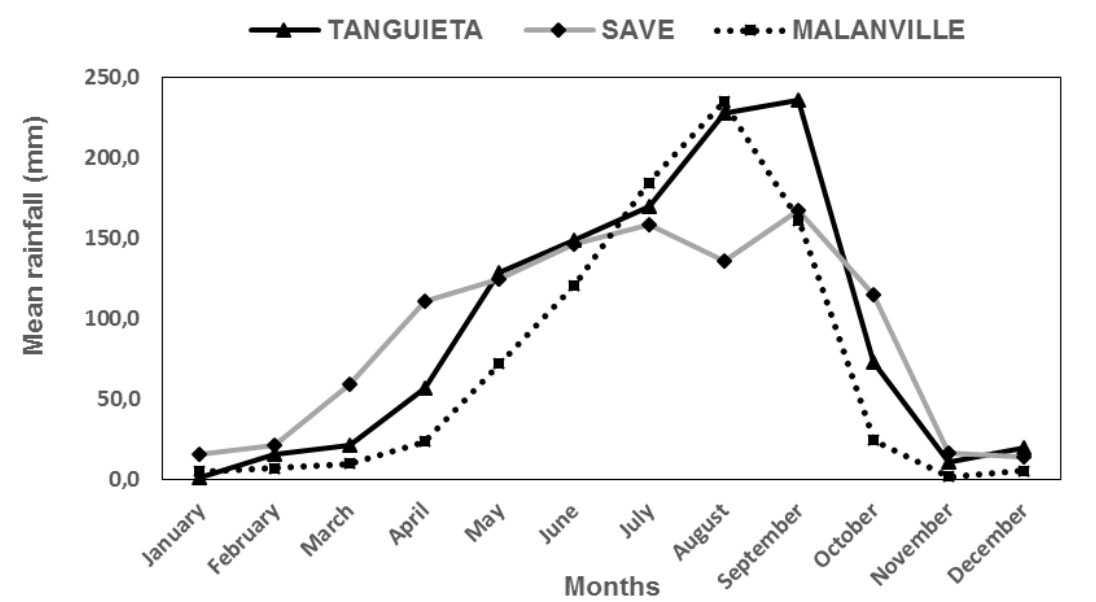

Fig. 2 Distribution of mean monthly rainfall of the 1970-2016 period 


\subsection{Methods}

\subsubsection{Preliminary analyses and compilation of rainfall data}

A day is considered to be a rainy day if the rainfall is $>0.1 \mathrm{~mm}$ (Lawin et al. 2011; Wabi et al. 2021). First, calendar months (January to December) were used to obtain monthly data by summing the daily rainfall for each month. Similarly, seasonal or yearly rainfall data were obtained by summing the corresponding monthly data. For a comprehensive and detailed evaluation of the seasonal rainfall, we grouped the monthly data according to a dry winter season (December to February), pre-monsoon season (March to May), monsoon season (June to September) and postmonsoon season (October and November), following Akinsanola and Ogunjobi (2017).

\subsubsection{Descriptive statistics}

Descriptive statistics were used to examine the variability of annual, seasonal and daily rainfall (Paul et al. 2017). Mean rainfall represents the central tendency. According to Hare (2003), the coefficient of variation (COV) can be divided into three groups representing: low variation ( $\mathrm{COV}<20 \%)$, moderate variation $(20 \% \leq \mathrm{COV} \leq 30 \%)$ and high variation $(\mathrm{COV}>30 \%)$. Skewness was calculated to describe the symmetry of a dataset while Kurtosis was computed and indicated the combined weight of the tails to the rest of the distribution.

\subsubsection{Standardized anomaly of rainfall (SAR)}

The inter-annual rainfall variability was analyzed using the standardized anomaly of rainfall (SAR) (Asfaw et al. 2018). The SAR was calculated as:

$$
\mathrm{Z}(i)=\frac{x i-\pi}{\theta}
$$

where $Z(i)$ is the standardized anomaly of rainfall of year $i$; $x_{i}=$ is the annual rainfall of year $i$; $\pi$ is the mean of the times series; and $\Theta$ is the standard deviation of the time series. A positive and negative $\mathrm{Z}(\mathrm{i})$ value indicates wet and dry years, respectively (Asfaw et al. 2018).

\subsubsection{Rainfall intensity}

We analyzed rainfall intensity in two complementary ways (Paul et al. 2017). First, total annual rainfall was divided by total rainy days in order to obtain the mean daily rainfall intensity. Secondly, we divided daily rainfall into four groups, i.e. light rainfall ( $<10 \mathrm{~mm}$ per day), moderate rainfall (10-25 $\mathrm{mm}$ per day), heavy rainfall $(25-50 \mathrm{~mm}$ per day), and extreme rainfall (> $50 \mathrm{~mm}$ per day) (Paul et al. 2017).

\subsubsection{Trend analyses}

We conducted a rigorous trend analysis by applying the non-parametric Mann-Kendall (MK), modified MK, and Sen's slope tests, using the annual, seasonal and daily rainfall (rainfall intensity) data. These analyses helped to determine the long-term upward, or downward trends of annual, seasonal, and daily rainfall. Statistical trend analysis was performed using a stepwise procedure (Fig. 3). 


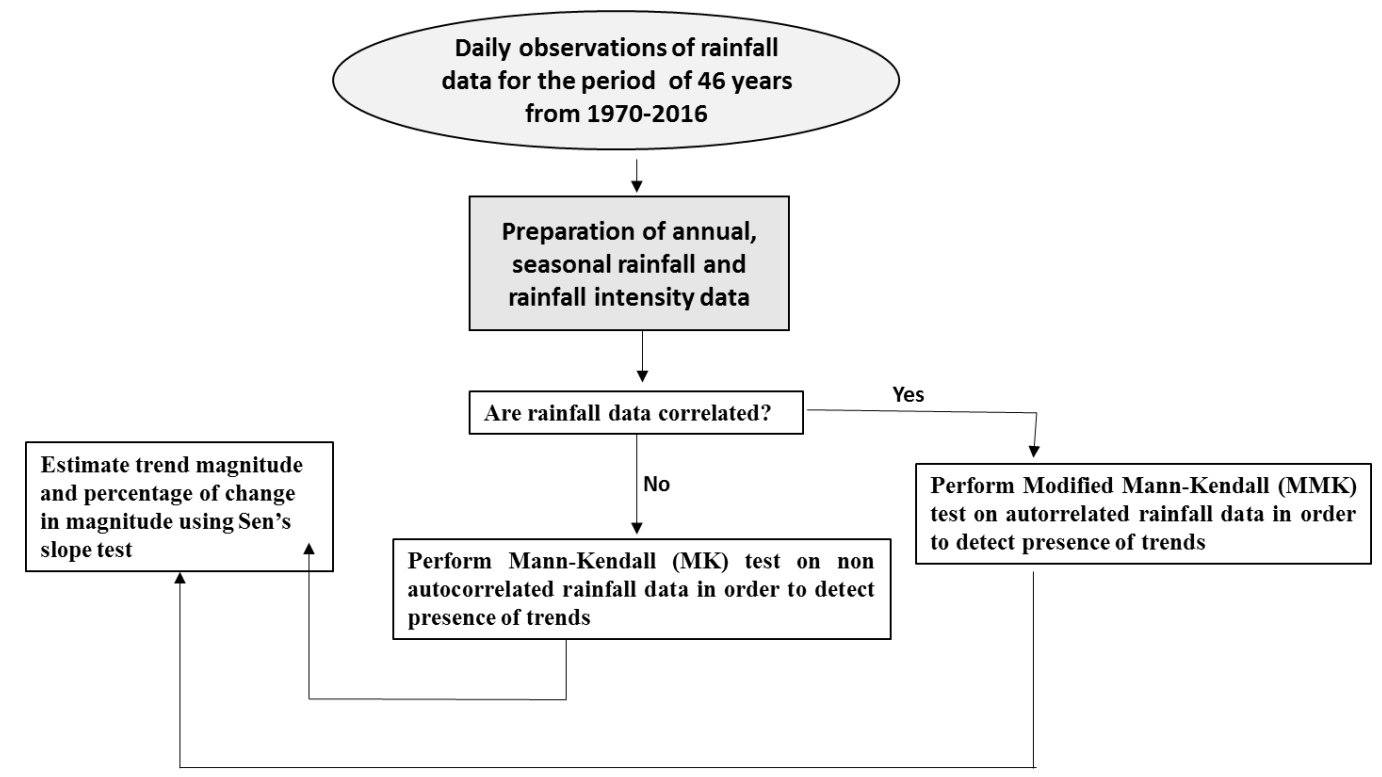

Fig. 3 The statistical analysis procedure adopted for trend analysis

\section{a. Auto-correlation test}

The auto-correlation function of ranks of the observations $\rho \mathrm{k}$ was calculated using the formula (Dodge 2003):

$$
\boldsymbol{\rho} \mathrm{k}=\frac{\left(\sum_{\mathrm{t}=\mathrm{k}+1}^{\mathrm{n}}\right)(\mathrm{yt}-\overline{\mathrm{Y}})\left(\mathrm{y}_{\mathrm{t}-\mathrm{k}}-\bar{Y}\right)}{\left(\sum_{\mathrm{t}=1}^{\mathrm{n}}(\mathrm{yt}-\overline{\mathrm{Y}})^{2}\right)}
$$

where $\bar{Y}$ is the mean of the times series ; $\mathrm{n}$ is the number of observations in the data series; $\mathrm{yt}_{\mathrm{t}}$ and $\mathrm{y}_{\mathrm{t}-\mathrm{k}}$ are the sequential data in the series.

The significance of the autocorrelation was checked within annual, seasonal and daily rainfall (rainfall intensity) data using Student's test at Lag-1 on rainfall data, following Akinsanola and Ogunjobi (2017):

$$
t=\sqrt[\rho 1]{(n-2) /\left(1-\rho 1^{2}\right)}
$$

where the test statistic has a t Student test distribution with ( $(\mathrm{n}-2)$ degrees of freedom, $\mathrm{n}=$ is the number of observations in the data series, and $\rho 1$ is the autocorrelation coefficient at Lag- 1 . If $|t| \geq t_{\alpha / 2}$, the null hypothesis regarding serial independence is rejected at a significant level $\alpha$.

\section{b. Mann-Kendall test (MK)}

The MK test was applied on the seasonal and annual rainfall and rainfall intensity data which were not found to be auto-correlated. The MK test was performed by using the formula (Mann 1975; Kendall 1975):

$$
\mathrm{S}=\sum_{\mathrm{i}=1}^{\mathrm{n}-1} \sum_{\mathrm{j}=\mathrm{i}+1}^{\mathrm{n}} \operatorname{sgn}(\mathrm{Xj}-\mathrm{Xi})
$$

where $\mathrm{n}$ is the number of observations in the data series; $\mathrm{Xj}$ and $\mathrm{Xi}(\mathrm{j}>\mathrm{i})$ are the sequential data in the series; and where the sign function is defined as :

$$
\operatorname{sgn}(\mathrm{Xj}-\mathrm{Xi})=\left\{\begin{aligned}
+1 & \text { if }(\mathrm{Xj}-\mathrm{Xi})>0 \\
0 & \text { if }(\mathrm{Xj}-\mathrm{Xi})=0 \\
-1 & \text { if }(\mathrm{Xj}-\mathrm{Xi})<0
\end{aligned}\right\}
$$


The variance of S was calculated following Mann (1975) and Kendall (1975):

$$
\operatorname{Var}(S)=\frac{\mathrm{n}(\mathrm{n}-1)(2 \mathrm{n}+5)-\sum_{\mathrm{p}=1}^{\mathrm{q}-1} \mathrm{tp}(\mathrm{tp}-1)(2 \mathrm{tp}+5)}{18}
$$

where $\mathrm{n}=$ is the number of observations in the data series, $\mathrm{q}=$ is the number of groups and tp $=$ is the size of the pth tied group.

In cases where the sample $\mathrm{n}>10$, the standard normal test statistic Z was computed as follows: (Mann, 1975; Kendall, 1975):

$$
Z=\left\{\begin{array}{cc}
\frac{S-1}{\sqrt{\operatorname{var}(S)}} & \text { if } S>0 \\
0 & \text { if } S=0 \\
\frac{S+1}{\sqrt{\operatorname{var}(S)}} & \text { if } S<0
\end{array}\right\}
$$

A positive $\mathrm{Z}$ value indicates that the direction of the trend is upward while a negative one that it is downward.

\section{c. Modified Mann-Kendall test (MMK)}

The MMK test (Hamed and Rao 1998; Akinsanola and Ogunjobi 2017; Paul et al. 2017) was employed to detect a trend in a time series of auto-correlated seasonal and annual rainfall and rainfall intensity data. The MMK allows calculating the auto-correlation between ranks of observation $\rho \mathrm{k}$ after taking out a non-parametric trend estimate. Only significant $\rho \mathrm{k}$-values were used to determine the variance correction factor $\left(\mathrm{n} / \mathrm{n}_{\mathrm{s}} *\right)(\mathbf{E q} \mathbf{8})$, because the variance of $\mathrm{S}$ calculated according to (Eq 4) is underestimated when data are auto-correlated.

$$
\frac{\mathrm{n}}{\mathrm{ns} \mathrm{s}^{*}}=1+\frac{2}{\mathrm{n}(\mathrm{n}-1)(\mathrm{n}-2)} \times \sum_{\mathrm{k}=1}^{\mathrm{n}-1}(\mathrm{n}-\mathrm{k})(\mathrm{n}-\mathrm{k}-1)(\mathrm{n}-\mathrm{k}-2) \rho \mathrm{k}
$$

where $\mathrm{n}=$ is the actual number of observations, $\mathrm{n}_{\mathrm{s}} *=$ is the effective number of observations accounting for autocorrelation in the time series and $\rho \mathrm{k}=$ is the auto-correlation function of ranks of the observations (Equation 2). Thus, the corrected variance is computed as:

$$
\mathrm{V}_{\mathrm{ar}}^{*}(\mathrm{~S})=\operatorname{Var}(\mathrm{S}) \mathrm{X} \frac{\mathrm{n}}{\mathrm{ns}^{*}}
$$

where $\operatorname{Var}(\mathrm{S})$ is described in (Equation 5). The standardized test statistic Z is then computed as in (Equation 6).

\section{d. Sen's slope estimator}

The non-parametric test of Sen's slope was employed to estimate the magnitude of the slope in the sample of $\mathrm{N}$ data pairs was developed by Sen (1968). The slope estimates of each data pair Qi is computed as:

$$
Q i=\left[\frac{(X i-X j}{(j-i)}\right] \text { for } i=1, \ldots, N
$$

where: $\mathrm{Xi}$ and $\mathrm{Xj}(\mathrm{j}>\mathrm{i})$ are considered as data values at the times $\mathrm{i}$ and $\mathrm{j}$, respectively.

If there are $\mathrm{X}_{\mathrm{i}}$-values in the time series, we have $\mathrm{N}=\frac{\mathrm{n}(\mathrm{n}-1)}{2}$ slope estimates. 
The values of Qi are ranked from small to large. Sen's slope is defined as the median value (Qmed) of this series, which is computed as:

$$
\text { Qmed }=\left\{\begin{array}{cc}
\mathrm{Q}_{\left[\frac{\mathrm{N}+1)}{2}\right]} & \text { if } \mathrm{N} \text { is odd } \\
\frac{1}{2}\left(\mathrm{Q}_{\left[\frac{\mathrm{N}}{2}\right]}+\mathrm{Q}_{\left.\left[\frac{(\mathrm{N}+2)}{2}\right]\right)}\right. & \text { if } \mathrm{N} \text { is even }
\end{array}\right\}
$$

A positive Qmed-value indicates an upward trend whereas a negative Qmed-value indicates a decreasing trend in the data series.

\section{e. Percentage of change in magnitude}

The percentage of change allowing comparison trends between different weather stations was calculated following Yue and Hashino (2003):

$$
\text { Percentage of change }(\%)=\frac{\text { Qmed } * \mathrm{n}}{\text { mean }} * 100
$$

where: Qmed = is the median of Sen's slope and $n=$ is the number of years.

In our study, a significance level of $\alpha=0.05$ was employed and all statistical analyses were performed using $\mathrm{R}$ version 3.6.1. (R Core Team 2019).

\section{Results}

\subsection{Inter-annual, seasonal and daily rainfall distribution and variability}

The lowest $(811 \mathrm{~mm})$ and highest $(1061 \mathrm{~mm})$ mean annual rainfall were recorded in Malanville (Sudano-Sahelian bioclimate) and Tanguiéta (Sudanian bioclimate), respectively (Table 2). In the three weather stations, the lowest mean rainfall and rainy days occurred during the dry winter season (December to February) while the monsoon season (June to September) had the highest mean rainfall and rainy days (Table 2). In the three weather stations, the highest and lowest mean number of rainy days were observed in the case of light rainfall ( $<10 \mathrm{~mm}$ per day) and extreme rainfall (> $50 \mathrm{~mm}$ per day), respectively (Table 2). The seasonal mean rainfall increased progressively from the dry winter season followed by the pre-monsoon season (March to May), reached the highest point during the monsoon season, and started decreasing in the post-monsoon season (October and November).

In Tanguiéta, the highest value of yearly rainfall $(1446 \mathrm{~mm})$ was recorded in 1998 while the lowest value (679 mm) was recorded in 1985 (Fig. 4). In Malanville, the highest value of yearly rainfall (1450 mm) was recorded in 2003 while the lowest value (472 mm) was recorded in 1973 (Fig. 4). In Savè, the highest (1486 mm) and the lowest (634 mm) yearly rainfall were recorded in 2003 and 1983, respectively (Fig. 4). The standardized anomaly of rainfall for the weather stations indicated that $51 \%, 57 \%$, and $53 \%$ of the years in the studies period experienced negative anomalies in Savè, Malanville and Tanguiéta, respectively (Fig. 5). Of this, more than 50\% of negative anomalies occurred between 1970 and 1994.

For the three weather stations, the dry winter and the post-monsoon season rainfall exhibited a high variability $(\mathrm{COV})$ of $>30 \%$ (Table 2$)$. The variability $(\mathrm{COV})$ of pre-monsoon season was $>30 \%$ in both Malanville and Tanguiéta while it showed a moderate variability in Savè (Table 2). The monsoon season rainfall showed a low coefficient of variation $(<20 \%)$ in Malanville and Tanguiéta and a moderate variability $(20 \% \leq \mathrm{COV} \leq 30 \%)$ in Savé (Table 2). The variability of rain in excess of $50 \mathrm{~mm}$ per day was very high $(\mathrm{COV}>30 \%)$ (Table 2) in the three 
weather stations. In general, in the whole year, light rainfall (<10 $\mathrm{mm}$ per day), moderate rainfall (10-25 mm per day) and heavy rainfall (25-50 mm per day) exhibited similar coefficient of variation (Table 2).

Table 2 Descriptive statistics of seasonal, annual and intensity of rainfall (1970-2016)

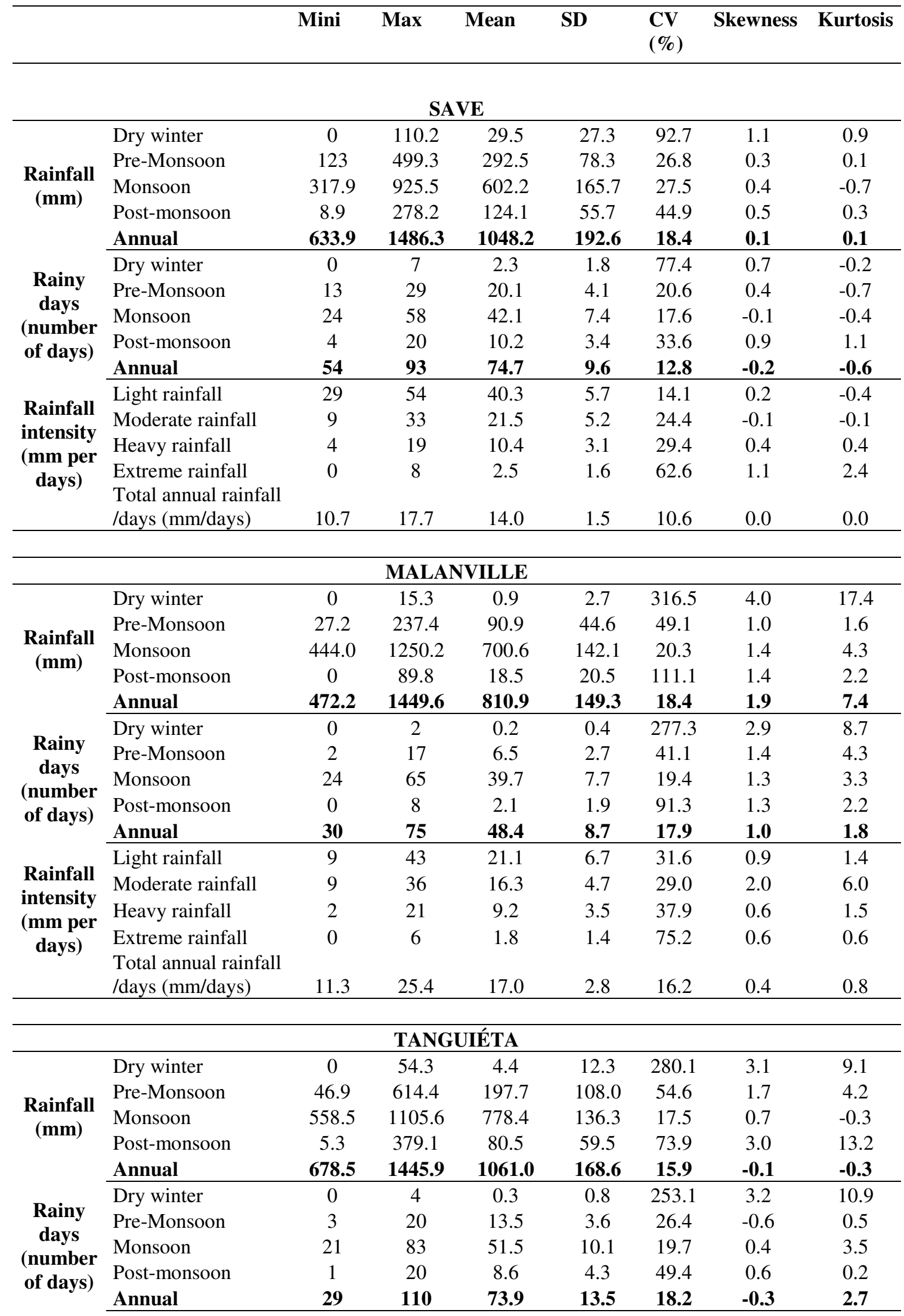




\begin{tabular}{|c|c|c|c|c|c|c|c|c|}
\hline \multirow{5}{*}{$\begin{array}{c}\text { Rainfall } \\
\text { intensity } \\
\text { (mm per } \\
\text { days) }\end{array}$} & Light rainfall & 7 & 76 & 38.2 & 10.7 & 28.1 & 0.5 & 3.5 \\
\hline & Moderate rainfall & 10 & 37 & 22.9 & 6.6 & 28.9 & 0.3 & -0.4 \\
\hline & Heavy rainfall & 3 & 20 & 10.1 & 3.2 & 32.0 & 0.6 & 1.4 \\
\hline & Extreme rainfall & 0 & 10 & 2.7 & 2.1 & 77.0 & 1.1 & 1.7 \\
\hline & $\begin{array}{l}\text { Mean rainfall } \\
\text { intensity ( } \mathrm{mm} / \text { days) }\end{array}$ & 9.5 & 27.7 & 14.7 & 3.1 & 21.0 & 2.4 & 7.9 \\
\hline
\end{tabular}

SD: standard deviation; $\mathrm{CV}$ : coefficient of variation 


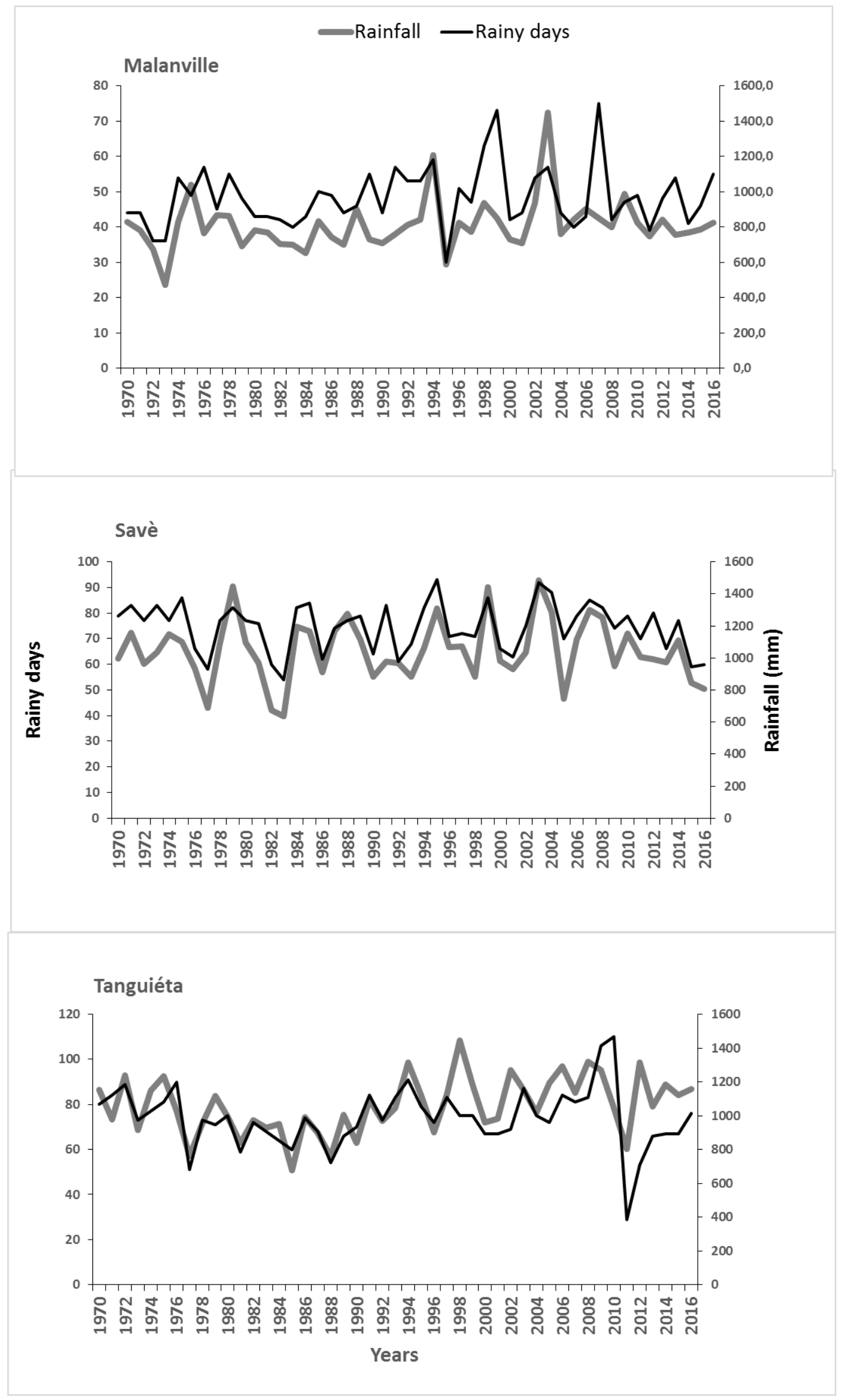

Fig. 4 Variability of annual rainfall and rainy days 


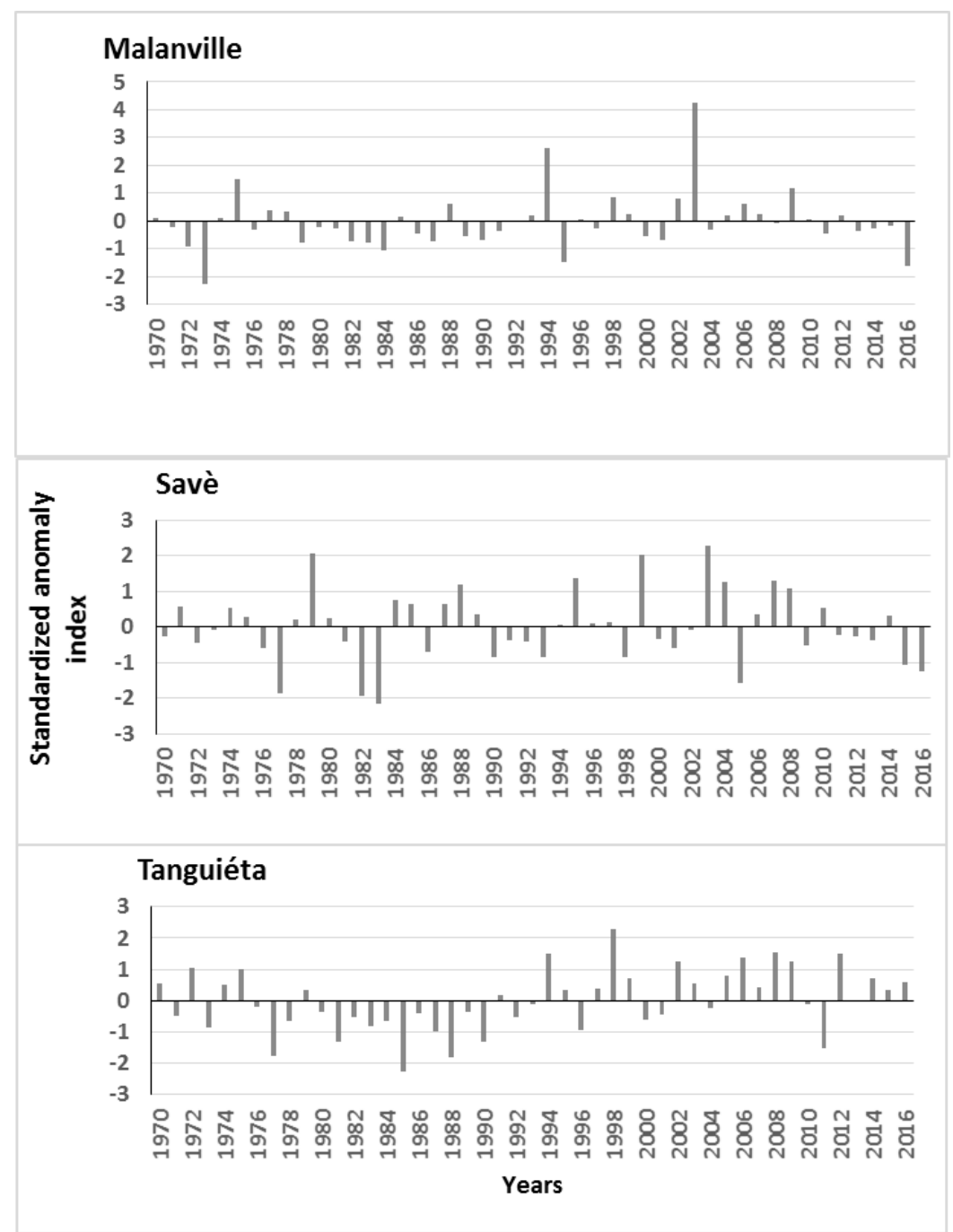

Fig. 5 Standardized anomaly index of annual rainfall during the period 1970-2016.

\subsection{Spatio-temporal pattern of rainfall trends}

Results indicate a significant increase $(\mathrm{p}=0.04)$ of $20 \%$ in the yearly rainfall in Tanguiéta, no significant change in Malanville ( $\mathrm{p}=0.150)$ and in Savè $(\mathrm{p}=0.83)$ (Table 3). No significant rainfall trend was observed in the monsoon season and the post-monsoon season in the three weather stations (Table 3). In the pre-monsoon season, the results indicated an increasing rainfall trend in Malanville (28\%) and Tanguiéta (59\%) while a decreasing trend (7\%) was observed in Savè. The trends were significant $(\mathrm{p}=0.02)$ in Tanguiéta and non-significant in Savè $(\mathrm{p}=0.37)$ and Malanville ( $\mathrm{p}=0.26)$ during the pre-monsoon season. A non-significant increase of rainfall was observed in the dry winter season in Savè $(\mathrm{p}=0.90)$ and Malanville $(\mathrm{p}=0.13)$ while a non-significant decrease was observed in Tanguiéta $(p=0.23)$. The results indicated a non-significant decrease trend of rainy days in both the pre-monsoon and monsoon seasons in Savè and Tanguiéta. The three weather stations recorded non-significant trends in both rainfall and rainy days during the post-monsoon season. In the weather station of Savè, a non-significant decreasing trend was observed in the number of days with light rainfall $(p=0.29)$, moderate rainfall $(p=0.73)$ and extreme rainfall $(p=0.91)$ whereas the number of days with heavy rainfall did not change significantly $(\mathrm{p}=0.15)$. In the weather station of Malanville no significant changes in light rainfall $(p=0.69)$, moderate rainfall $(p=0.84)$, heavy rainfall $(p=0.49)$ or extreme rainfall $(p=0.30)$ were observed. In the weather station of Tanguiéta, no significant changes were observed in light rainfall 
$(p=0.35)$ and moderate rainfall $(p=0.10)$, whereas a significant increase trend was recorded in both heavy $(p=0.04)$ and extreme rainfall $(\mathrm{p}=0.03)$.

Table 3 Result of Mann-Kendall (Modified Mann-Kendall) test (at 0.05 level) and percentage change over 1970-2016

\begin{tabular}{|c|c|c|c|c|}
\hline & & & Z-value & $\%$ change \\
\hline \multirow{15}{*}{$\begin{array}{l}\text { Rainfall } \\
\text { (mm) }\end{array}$} & \multirow{5}{*}{ Savè } & Annual & -0.18 & -0.58 \\
\hline & & Dry (winter) & 0.58 & 0.00 \\
\hline & & Pre-monsoon & -0.89 & -7.23 \\
\hline & & Monsoon & 0.46 & 5.58 \\
\hline & & Post-monsoon & 0.99 & 20.48 \\
\hline & \multirow{5}{*}{ Malanville } & Annual & 1.45 & 9.91 \\
\hline & & Dry (winter) & 1.52 & 0.00 \\
\hline & & Pre-monsoon & 1.14 & 27.97 \\
\hline & & Monsoon & 0.77 & 7.95 \\
\hline & & Post-monsoon & 0.02 & 0.00 \\
\hline & \multirow{5}{*}{ Tanguiéta } & Annual & $1.98 *$ & 19.47 \\
\hline & & Dry (winter) & -1.2 & 0.00 \\
\hline & & Pre-monsoon & $2.38 *$ & 58.91 \\
\hline & & Monsoon & 0.48 & 3.08 \\
\hline & & Post-monsoon & 0.55 & 7.77 \\
\hline \multirow{15}{*}{$\begin{array}{l}\text { Rainy days } \\
\text { (number) }\end{array}$} & \multirow{5}{*}{ Savè } & Annual & -0.66 & -5.18 \\
\hline & & Dry (winter) & 0.58 & 0.00 \\
\hline & & Pre-monsoon & -0.12 & 0.00 \\
\hline & & Monsoon & -0.83 & -7.78 \\
\hline & & Post-monsoon & 0.51 & 0.00 \\
\hline & \multirow{5}{*}{ Malanville } & Annual & 0.86 & 7.77 \\
\hline & & Dry (winter) & 1.30 & 0.00 \\
\hline & & Pre-monsoon & 0.82 & 0.00 \\
\hline & & Monsoon & 0.16 & 0.00 \\
\hline & & Post-monsoon & 1.35 & 0.00 \\
\hline & \multirow{5}{*}{ Tanguiéta } & Annual & -0.19 & -1.51 \\
\hline & & Dry (winter) & $-1,37$ & 0.00 \\
\hline & & Pre-monsoon & -0.86 & -10.89 \\
\hline & & Monsoon & -0.25 & -1.99 \\
\hline & & Post-monsoon & 0.66 & 0.00 \\
\hline \multirow{15}{*}{$\begin{array}{l}\text { Rainfall intensity } \\
\text { (mm per day) }\end{array}$} & \multirow{5}{*}{ Savè } & $<10 \mathrm{~mm}$ & -1.10 & -10.61 \\
\hline & & 10 to 25 & -0.35 & 0.00 \\
\hline & & 25 to 50 & 1.40 & 19.88 \\
\hline & & $>50 \mathrm{~mm}$ & -0.11 & 0.00 \\
\hline & & Mean rainfall intensity & 1.57 & 6.05 \\
\hline & \multirow{5}{*}{ Malanville } & $<10 \mathrm{~mm}$ & 0.39 & 0.00 \\
\hline & & 10 to 25 & -0.20 & 0.00 \\
\hline & & 25 to 50 & 0.69 & 0.00 \\
\hline & & $>50 \mathrm{~mm}$ & 1.05 & 0.00 \\
\hline & & Mean rainfall intensity & 0.94 & 6.63 \\
\hline & \multirow{5}{*}{ Tanguiéta } & $<10 \mathrm{~mm}$ & -0.94 & -8.79 \\
\hline & & 10 to 25 & -1.65 & -24.15 \\
\hline & & 25 to 50 & $2.10 *$ & 31.13 \\
\hline & & $>50 \mathrm{~mm}$ & $2.20 *$ & 74.45 \\
\hline & & Mean rainfall intensity & $2.60 *$ & 19.27 \\
\hline
\end{tabular}

MMK values in bold indicate the presence of auto-correlation in the time series; Positive/negative Z-value represents increasing/decreasing trend; * shows a significant trend for $\alpha=0.05$. 


\section{Discussion}

\subsection{Rainfall variability and trends}

For all weather stations, the degree of variability of yearly rainfall, expressed by the low coefficient of variation might be linked to atmospheric factors such as the El Niño and La Niña episodes, the position of the Inter-Tropical Convergence Zone (ITCZ), the African Easterly Jet (AEJ), and the Tropical Easterly Jet (TEJ) (Tadeyo et al. 2020). Recently, a strong linkage was found between annual rainfall variability in Benin and climate oscillation indices such as the Pacific Decadal Oscillation, Dipole Mode Index (Ahokpossi 2018). The standardized anomaly of rainfall for the weather stations indicated that $50 \%$ of negative anomalies occurred between 1970 and 1994. Most negative anomalies that occurred between 1970 and 1994 in the three weather stations refer to dry years. In Benin, significant droughts occurred over the period 1977-1983 (MCVDD 2019). On the other hand, positive anomalies observed in general between 1994 and 2010 indicates the return of wet years.

For the three weather stations, the dry winter and the post-monsoon season rainfall exhibited a high variability indicating that these seasons received less rainfall than the other seasons. During the post-monsoon season, the St. Helena High-pressure systems started moving to lower latitudes and the Inter-Tropical Convergence Zone (ITCZ) began to return and thereby resulting in this minor rainy season (Ahokpossi 2018). During this period, rainfall became erratic and its variability (COV) increased above 30\%. From the pre-monsoon season, the coefficient of variation $(\mathrm{COV})$ started decreasing indicating the return of rainy season after a long period of drought across all the three weather stations. During this season, the Azores high pressure systems started to weaken as the St Helena high pressure system began to intensify (Tadeyo et al. 2020). At this moment, the ITCZ rised from its southern position and started migrating towards the North which coming with the moisture conditions. The pre-monsoon season is referred to the period of the onset of rainy season in the three weather stations (Wabi et al. 2021). The low and moderate variability during the monsoon season indicated that rainfall was relatively plentiful. The monsoon season (June to September) was the wettest season in the three weather stations, indicating the strength of the St. Helena High-pressure system which may have intensified and the moisture-laden South-West Monsoon winds started dominating and pushing the Inter-Tropical Convergence Zone (ITCZ) to the North over the country (Benin) (Ahokpossi 2018). The monsoon season (June to September) was found as the main seasonal rainfall in many states of Nigeria (Akinsanola and Ogunjobi 2017). The high variability of rain in excess of $50 \mathrm{~mm}$ per day in the three weather stations indicating that this group of rain might be rare, irregular and unpredictable, but when it may occur can result in serious consequences such as flooding and topsoil degradation (Salack et al. 2018) while light rainfall, moderate rainfall and heavy rainfall were regular and contributed to the seasonal and yearly rainfall in the three weather stations.

The observed trends in the yearly rainfall shows evidence that the annual rainfall trend is still uncertain across region (Ademe et al. 2020; IPCC 2021), since rain is a variable that change with time and space. Similar findings were found in Benin climate trends which revealed significant increasing annual rainfall trends (Idrissou et al. 2020) and insignificant annual rainfall trends (Ahokpossi 2018). The decrease of rainfall in the pre-monsoon may explain the decrease of annual rainfall in the weather station of Savè. Recent studies found dry spells occurring during the premonsoon and the monsoon season in some regions (e.g. Glazoué) in the center of Benin (Niang et al. 2018; Wabi et al. 2021). A significant increase of annual rainfall observed at Tanguiéta may be attributed to the significant increase of the pre-monsoon season rainfall due to the significant increase of heavy and extreme rainfall. The occurrence of significant increasing of heavy and extreme rainfall observed in Tanguiéta may be attributed to climate change. The 
sixth report from the Intergovernmental Panel on Climate Change (IPCC) projects that extreme rainfall episodes are expected to increase in intensity and frequency as a result of climate change (IPCC 2021).

\subsection{Potential impact of the observed rainfall trends on agriculture}

The ability to detect trends in the long-term rainfall time series is very important to prevent the adverse effects of droughts or floods in agricultural production (Gummadi et al. 2018; Salack et al. 2018; Ademe et al. 2020). In Benin, agricultural production depends fundamentally on the climatic conditions, as majority of crop is produced under rainfed conditions with only less than 1\% into irrigation farming (Malabo Montpellier Panel 2018; Zougmoré et al. 2018; Wabi et al. 2021) (Fig. 6). Farmers therefore struggle to adapt to the currently increasing rainfall variability (Ezin et al. 2018; MCVDD 2019; Arouna et al. 2021). The observed trends in seasonal, annual and daily rainfall are expected to have a significant impact on agriculture.

The general rainfall increase observed during the post-monsoon season in the three weather stations potentially increases flood frequencies during the harvest period of some crops (Fig. 6), which can reduce crop yields. For instance, pepper production in both the Sudano-Sahelian bioclimate and Sudanian bioclimate and rain-fed rice crop in Sudano-Guinean transition zone may be seriously affected by floods, as the harvest period is entirely in the postmonsoon season (Fig. 6).

In the weather station of Savè, the decreasing trends of rainy days and rainfall amount in the whole year as well as during the pre-monsoon have a high potential impact on the performance of agricultural systems (Gummadi et al. 2018; Wabi et al. 2021), threatening future agricultural production in the Sudano-Guinean agro-ecological transition zone. The observed trends would increase the prevalence of droughts and ultimately will have a negative impact on livestock by the decreasing availability of weeds and grasslands for animal fodder and the availability of water for animals (e.g., cattle), as was observed by Idrissou et al. (2020) in Benin. Decreasing trends in both rainfall amounts and number of rainy days in the pre-monsoon season are likely to reduce soil moisture content which results in hard soils that are difficult to till, thus increasing the risk of the crop failure (e.g., delayed planting times, low seed germination and poor seedling growth) for most crops (Fig. 6). Ultimately, the decreasing trends in the number of rainy days in the monsoon season coupled with decreasing rainfall in the pre-monsoon season will lead to high prevalence of prolonged dry spells and erratic distribution of rainfall that could have a negative impact on agricultural production by affecting plant growth, altering the flowering and grain filling phase and reducing crop yields. For instance, the sowing period of rain-fed rice, maize, and cucumber crops (Fig. 6) and their grow period may be problematic as the planting period is entirely within the monsoon season. This was supported by Ezin et al. (2018) who reported that the 2009 rainy season had definitively stopped in June at the beginning of the monsoon season, which resulted in significant yield reductions (i.e., maize and tomato). Recently, Niang et al. (2018) reported that the long delay in rice planting reduces rice yields during the monsoon season in the Sudano-Guinean transition agroecological zone (e.g. Glazoué). Other studies reported in the Sudano-Guinean transition agro-ecological zone, no appropriate date for rain-fed rice, due to the very high probabilities ( 0.7 to 1 ) of dry period at flowering stage (Wabi et al. 2021). A $20 \%$ increase of heavy rainfall is likely to increase the risk of flood while a decrease of light, moderate and extreme rainfall may increase the risk of drought and poor spatial distribution of rainfall. Subsequent floods and droughts within a year may increase soil erosion and land degradation (Oyerinde et al. 2017; Salack et al. 2018).

The increasing trends of rainfall intensity and of annual yearly, pre-monsoon and monsoon rainfall, observed in Malanville, will have a positive impact on crop and livestock production systems in the Sudano-Sahelian agroecological zone. However, these trends may negatively affect the harvest period of irrigated rice (Fig. 6) which occurs 
in the pre-monsoon and monsoon seasons. The insignificant increasing trends observed in heavy rainfall (25 to 50 $\mathrm{mm})$ and extreme rainfall $(>50 \mathrm{~mm}$ ) are expected to increase the prevalence of floods and land degradation in this region (Salack et al. 2018). Excessive rainfall in the monsoon season may affect the sowing period of many food crops (Fig. 6) and can cause waterlogging and severe erosion (Ademe et al. 2020) in the Sudano-Sahelian of the extreme North agro-ecological zone. Oyerinde et al. (2017) reported that the majority (90\%) of farmers considered floods as the major hydrological challenge for crop, livestock-rearing, and fishing in the Sudano-Sahelian agro-ecological zone of the extreme North.

In the Sudanese North-West agro-ecological zone, the increasing trends in the yearly, pre-monsoon and monsoon rainfall will have a positive impact on crop and livestock production systems. However, the decreasing trends observed in the number of pre-monsoon rainy days may hamper the emergence of yam tubers in the Sudanian zone. Adifon et al. (2020) found that the rainfall delay in the pre-monsoon season is a temporal factors that affecting the yield of yams in the Sudanian regions of Benin. The significant increases of heavy and extreme rainfall are likely to negatively affect the growing season period with a very high risk of floods (Salack et al. 2018). Furthermore, heavy and extreme rainfall increase land degradation, runoff and agricultural topsoil erosion (Oyerinde et al. 2017; Ademe et al. 2020), which affects soil fertility. 


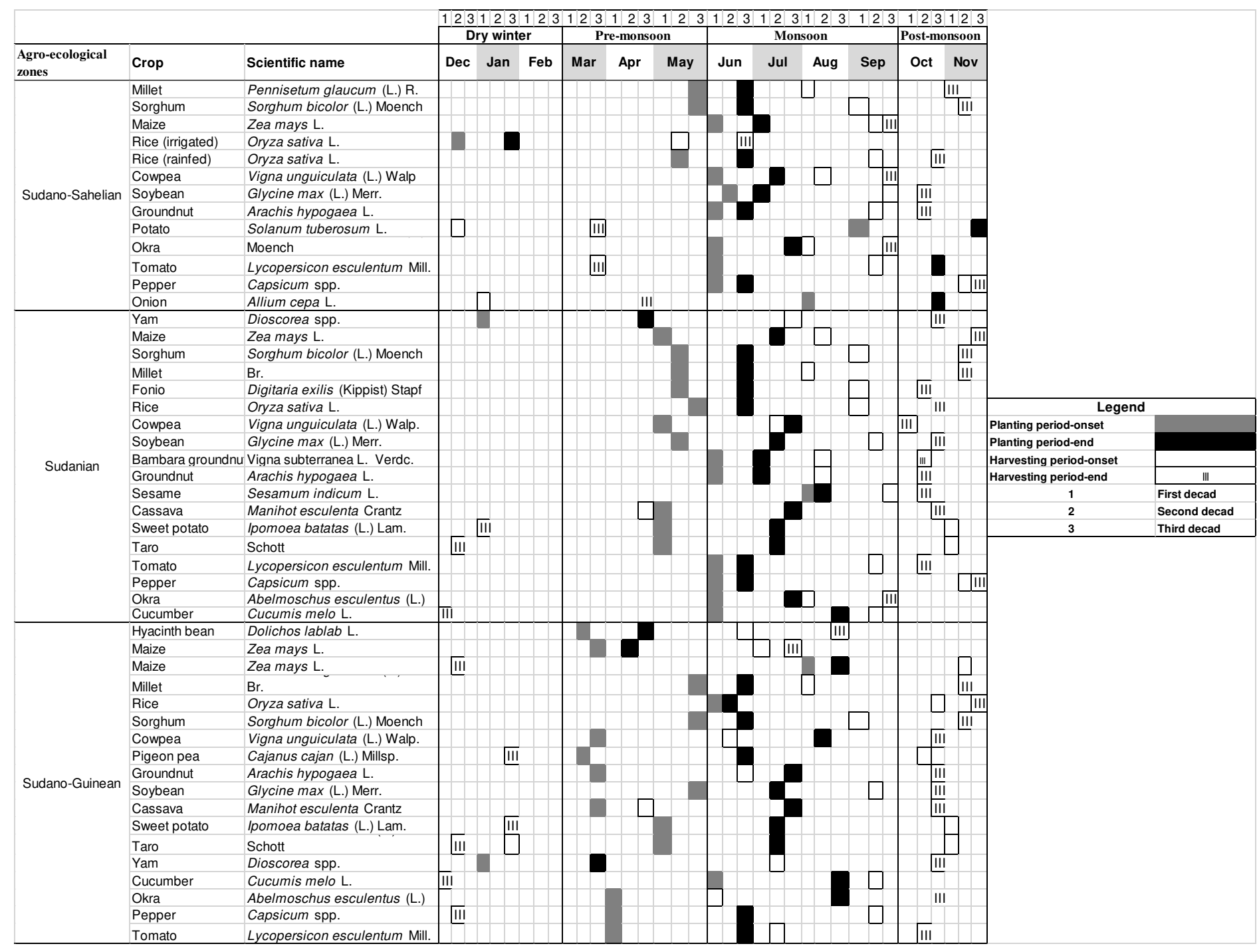

Fig. 6. Crop calendar: planting and harvest seasons for main food crops.

Data assembled from Aho et al. (2018) and FAO (2021). 


\section{Conclusions}

Understanding the spatio-temporal variability and trends in annual, seasonal, and daily rainfall can provide useful information for better planning water resources management and help to design appropriate adaptation measures in agriculture which is largely dependent on weather conditions. The spatio-temporal rainfall variability and trends revealed in our study, clearly indicate that in Benin, considerable changes are taking place in terms of annual, seasonal and daily rainfall for the 1970-2016 period as they were observed at the weather stations of Savè, Malanville, and Tanguiéta in Benin. Globally, moderate-to-high seasonal rainfall and low variability of annual rainfall were observed. The standardized anomaly of rainfall for the weather stations indicated that more than $50 \%$ of the years in the studies period experienced dry years between 1970 and 1994. The variability and trends in yearly and in seasonal rainfall were attributed to the daily rainfall. The general rainfall increase observed during the post-monsoon season in the three weather stations potentially increases flood frequencies during the harvest period of some crops, which can reduce crop yields. In the weather station of Savè, the decreasing trends of rainy days and rainfall amount in the whole year as well as during the pre-monsoon have a high potential impact on the performance of agricultural systems. However, the increasing trends of rainfall intensity and of annual yearly, pre-monsoon and monsoon rainfall, observed in Malanville, will have a positive impact on crop and livestock production systems. The significant increasing trends observed in heavy and extreme rainfall are expected to increase the prevalence of floods and land degradation in Tanguiéta. In general, our findings indicated that the flood risk is expected to be higher in all agro-ecological zones under consideration. The observed trends in rainfall can have serious consequences on agricultural production, certainly when no adaptation strategies are applied. These findings are extremely important for the management and planning of agricultural activities. Agricultural strategies are needed which can mitigate these risks and make agricultural production more resilient to the adverse effects of climate change. 


\section{References}

Ademe D, Ziatchik BF, Tesfaye K, Simane B, Alemayehu G, Adgo E (2020) Climate trends and variability at adaptation scale: Patterns and perceptions in an agricultural region of the Ethiopian Highlands. Weather Clim. Extrem 29 : 100263. https://doi.org/10.1016/j.wace.2020.100263

Adifon FH, Atindogbe G, Bello DO, Balogoun I, Yabi I, Dossou J, Ahoton L, Saidou A (2020) Effect of climate variability on yams (Dioscorea spp.) production in Central and Northern Benin. AJCC 9: 423-440. https://doi.org/10.4236/ajcc.2020.94027

AGVSA (2017). Analyse globale de la vulnérabilité et la sécurité alimentaire (AGVSA) au Bénin. Programme Alimentaire Mondial des Nations Unies (PAM), Service de l'Analyse et de la Sécurité Alimentaire (VAM), Siège social: Via C.G. Viola 68, Parco de Medici, 00148, Rome, Italie, 171p

Aho N, Aho S, Agbokou I, Kaffo BA, Seni S, Loconon DZ (2018) Introduction à la résilience aux changements climatiques en Afrique de l'Ouest : répertoire des dates prédéterminées des saisons pluvieuses dans les villages et quartiers de ville du Bénin. Ministère de l'Energie, de l'Eau et des Mines-PNUD Bénin, Cotonou

Ahokpossi Y (2018) Analysis of the rainfall variability and change in the Republic of Benin (West Africa). Hydrol. Sci. J 63 (15-16): 2097-2123. https://doi.org/10.1080/02626667.2018.1554286

Akinsanola AA, Ogunjobi KO (2017). Recent homogeneity analysis and long-term spatio-temporal rainfall trends in Nigeria. Theor. Appl. Climatol 128 : 275-289 https://doi.org/10.1007/s00704-015-1701-X

Akumaga U, Tarhule A (2018) Projected changes in intra-season rainfall characteristics in the Niger River Basin, West Africa. Atmosphere 9 (12): 497. https://doi.org/10.3390/atmos9120497

Arouna A, Fatognon IA, Saito K, Futakuchi K (2021) Moving toward rice self-sufficiency in sub-Saharan Africa by 2030: lessons learned from 10 years of the Coalition for African Rice Development. World Development Perspectives 21. http://creativecommons.org/licenses/by/4.0/

Asfaw A, Simane B, Hassen A, Bantider A (2018) Variability and time series trend analysis of rainfall and temperature in northcentral Ethiopia: a case study in Woleka sub-basin. Weather Clim. Extrem 19: 29-41, https://doi.org/10.1016/j.wace.2017.12.002

Cornelissen T, Diekkrüger B, Giertz S (2013) A comparison of hydrological models for assessing the impact of land use and climate change on discharge in a tropical catchment. J. Hydrol. 498 : 221-236

Dodge Y (2003) Statistique dictionnaire encyclopédique. Groupe statistique, Université de Neuchâtel, Espace de l'Europ 4, Case postale 805, 2002 Neuchâtel, Suisse

Ezin V, Yabi I, Kochoni EGM, Ahanchédé A (2018). Agriculture and food security under climate change threat in Benin. Afr. J. Agric. Res. 13 (27): 1389-1399

FAO (2021) Crop calendar: an information tool for seed security. http://www.fao.org/agriculture/seed/cropcalendar/welcome.do. Accessed 12 June 2021

Gnanglé CP, Glèlè Kakaï R, Assogbadjo AE, Vodounnon S, Yabi JA, Sokpon N (2011) Tendances climatiques passées, modélisation, perceptions et adaptations locales au Bénin. Climatologie 8 : 27-39

Gummadi S, Rao KPC, Seid J, Legesse G, Madiyala MDM, Takele R, Amede T, Whitbread A (2018) Spatio-temporal variability and trends of precipitation and extreme rainfall events in Ethiopia in 1980-2010. Theor. Appl. Climatol 134 : 315-1328. https://doi.org/10.1007/s00704-017-2340-1

Hamed KH, Rao R (1998) A modified Mann-Kendall trend test for autocorrelated data. J. Hydrol., 204(1-4): 182-196

Hare W (2003) Assessment of knowledge on impacts of climate change: contribution to the specification of art, 2 of the UNFCCC. WBGU

Idrissou Y, Seidou AA, Tossou FM, Worogo HSS, Baco MN, Adjassin JS, Assogba BGC, Traore IA (2020). Perception du changement climatique par les éleveurs de bovins des zones tropicales sèches et subhumide du Béni : comparaison avec les données météorologiques. Cah. Agric, 29(1): 1-9. https://doi.org/10.1051/cagri/2019032

IPCC (2021) Summary for Policymakers. In: Climate Change 2021: The Physical Science Basis. Contribution of Working Group I to the Sixth Assessment Report of the Intergovernmental Panel on Climate, Change [MassonDelmotte, V., P. Zhai, A. Pirani, S. L. Connors, C. Péan, S. Berger, N. Caud, Y. Chen, L. Goldfarb, M. I. Gomis, 
M. Huang, K. Leitzell, E. Lonnoy, J.B.R. Matthews, T. K. Maycock, T. Waterfield, O. Yelekçi, R. Yu and B. Zhou (eds.)]. Cambridge University Press

Kendall MG (1975) Rank Correlation Methods. Charles Griffin, London

Lawin AE, Afouda A, Lebel T (2011) Analyse de la variabilté du régime pluviométrique dans la région agricole d'Ina au Bénin. Eur. J. Sci. Res., 50(3) : 445-439

Lawin IF, Lalèyè OAF, Agbani OP (2016) Vulnérabilité et stratégies endogènes de conservation des plantes utilisées dans le traitement du diabète dans les communes de Glazoué et Savè au Centre-Bénin. Int. J. Biol. Chem. Sci. 10(3): 1069-1085

Lawin AE, Hounguè NR, Biaou CA, Badou DF (2019) Statistical analysis of recent and future rainfall and temperature variability in the Mono River Watershed (Benin, Togo). Climate 7 (8) : 1-17 https://doi.org/10.3390/cli7010008

MAEP (2017) Plan Stratégique de Développement du Secteur Agricole (PSDSA) 2025 et Plan National d'Investissements Agricoles et de Sécurité Alimentaire et Nutritionnelle PNIASAN 2017-2021, version finale mai 2017. Ministère de l'Agriculture de l'Elevage et de la Pêche 139p

Malabo Montpellier Panel (2018) Water-wise: smart irrigation strategies for Africa: Benin. Dakar. December 2018

Mann HB (1945) Nonparametric tests against trend. Econometrica 13: 245-259

Marie M, Yirga F, Haile M, Tquabo F (2020) Farmers' choices and factors affecting adoption of climate change adaptation strategies: evidence from north-western Ethiopia. Heliyon 6 (4) : e03867

MCVDD (2019) Troisième Communication Nationale (TCN) sur les changements climatiques. Ministère du Cadre de Vie et du Développement Durable, Cotonou, Bénin, 354p

Niang A, Becker M, Ewert F, Tanaka A, Dieng I, Saito K (2018) Yield variation of rainfed rice as affected by field water availability and $\mathrm{N}$ fertilizer use in central Benin. Nutr. Cycl. Agroecosystems 110: 293-305. https://doi.org/10.1007/s10705-017-9898-y

Onyutha C (2018) African crop production trends are insufficient to guarantee food security in the sub-Saharan region by 2050 owing to persistent poverty. Food Security, http://dx.doi.org/10.1007/s12571-018-0839-7

Oyerinde GT, Lawin AA, Odofin AJ (2017) Farmers' responses to changing hydrological trends in the Niger bassin parts of Benin. Hydrology 4: 52. https://www.mdpi.com/2306-5338/4/4/52

Paul A, Bhowmik R, Chowdary VM, Dutta D, Sreedhar U, Sankar HR (2017) Trend analysis of time series rainfall data using robust statistics. J Water Clim Change 8(4): 691-700

R Core Team (2019) R: A language and environment for statistical computing. R Foundation for Statistical Computing, Vienna, Austria. URL https://www.R-project.org/

Salack S, Saley IA, Lawson NZ, Zabré I, Daku EK (2018) Scales for rating heavy rainfall events in the West African Sahel. Weather Clim. Extrem. 21: 36-42, https://doi.org/10.1016/j.wace.2018.05.004

Sen PK (1968) Estimates of the regression coefficient based on Kendall's tau. J. Am.Stat. Assoc. 63, 1379-1389

Sylla MB, Giorgi F, Pal JS, Gibba P, Kebe I, Nikiema M (2015) Projected changes in the annual cycle of high-intensity precipitation events over West Africa for the late twenty-first century. Int. J. Climatol 28: 6475-6488

Tadeyo E, Chen D, Ayugi B, Yao C (2020) Characterization of spatio-temporal trends and periodicity of precipitation over Malawi during 1979-2015. Atmosphere 11: 891, https://doi.org/10.3390/atmos11090891.

Tang YH, Luan XB, Sun JX, Zhao JF, Yin YL, Wang YB, Sun SK (2021) Corrigendum to « impact assessment of climate change and human activities on GHF emissions and agricultural water use ». Agric For Meteorol. 296. https://doi.org/10.1016/j.agrformet.2020.108218

Wabi MA, Vanhove W, Idohou R, Hounkpèvi A, Glèlè Kakaï RL, Van Damme P (2021) Risques agrométéorologiques et production du riz pluvial (Oryza spp.) au Bénin (Afrique de l'Ouest). Sciences de la Vie, de la Terre et Agronomie 9(2) : 73-80

Yue S, Hashino M (2003) Long term trends of annual and monthly precipitation in Japan. J Am Water Resource Association 39(3): 587-596. https://doi.org/10.1111/j.1752-1688.2003.tb03677.x 
Yue S, Pilon P, Phinney B, Cavadias G (2002) The influence of auto-correlation on the ability to detect trend in hydrological series. Hydrol. Process 16: 1807-1829. https://doi.org/10.1002/hyp.1095

Zougmoré RB, Partey ST, Ouédraogo M, Torquebiau E, Campbell BM (2018) Facing climate variability in subSaharan Africa: analysis of climate-smart agriculture opportunities to manage climate-related risks. Cah. Agric 27: 2-9. https://doi.org/10.1051/cagri/2018019

\section{Author contribution}

Moudjahid Akorédé Wabi : conceptualization, methodology, data analysis, writing-original draft. Wouter Vanhove : participation in project designing, data analysis, and writing-review \& editing. Rodrigue Idohou and Achille Hounkpèvi : participation in statistical analysis of data and writing-review \& editing. Romain Lucas Glèlè Kakaï and Patrick Van Damme : participation in project design, data analysis, writing-review \& editing, and supervision of the study.

\section{Funding}

This work was supported by Ghent University (UGENT) [scholarship code: 01W00414, 2014]; and International Foundation for Science [Grant Agreement $\left.\mathrm{N}^{\circ} \mathrm{C} / 5762-1,2015\right]$ to the first author.

\section{Acknowledgments}

Our acknowledgment goes to Ghent University, International Foundation for Science and also to Dr Sylvanus Mensah, whose useful comments helped improve the quality of this document.

\section{Data availability}

The datasets generated during and/or analysed during the current study are available from the corresponding author on reasonable request.

\section{Declaration}

Ethics approval: The authors declare that there is no human or animal participant in the study. Not applicable.

Consent to participate: The authors declare that there is no human or animal participant in the study. Not applicable.

Consent for publication: The authors give their consent to the publication of all details of the manuscript including texts, figures, and tables.

Conflict of interest : The authors declare no competing interests. 